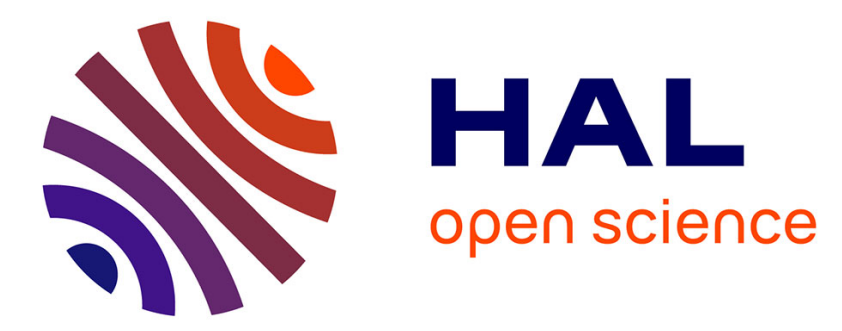

\title{
Partial purification and characterization of a copper-induced anionic peroxidase of sunflower roots
}

Hager Jouili, Houda Bouazizi, Michel Rossignol, Gisèle Borderies, Elisabeth Jamet, Ezzeddine El Ferjani

\section{- To cite this version:}

Hager Jouili, Houda Bouazizi, Michel Rossignol, Gisèle Borderies, Elisabeth Jamet, et al.. Partial purification and characterization of a copper-induced anionic peroxidase of sunflower roots. Plant Physiology and Biochemistry, 2008, 46 (8-9), pp.760-7. 10.1016/j.plaphy.2008.04.006 . hal-00315669

\section{HAL Id: hal-00315669 \\ https://hal.science/hal-00315669}

Submitted on 29 Aug 2008

HAL is a multi-disciplinary open access archive for the deposit and dissemination of scientific research documents, whether they are published or not. The documents may come from teaching and research institutions in France or abroad, or from public or private research centers.
L'archive ouverte pluridisciplinaire HAL, est destinée au dépôt et à la diffusion de documents scientifiques de niveau recherche, publiés ou non, émanant des établissements d'enseignement et de recherche français ou étrangers, des laboratoires publics ou privés. 
Published in Plant Physiol Biochem (2008) 46, 760-767

\section{Partial purification and characterization of a copper-induced anionic peroxidase of sunflower roots}

Running title: Copper oxidative stress in sunflower

Author's names: Hager Jouili ${ }^{\mathrm{a}}$, Houda Bouazizi ${ }^{\mathrm{a}}$, Michel Rossignol ${ }^{\mathrm{b}}$, Gisèle Borderies ${ }^{\mathrm{b}}$, Elisabeth Jamet ${ }^{\mathrm{c}}$, Ezzeddine El Ferjani ${ }^{\mathrm{a}^{*}}$

\section{Author's adresses:}

a Laboratoire de Biologie et Physiologie Cellulaires, Faculté des Sciences de Bizerte, 7021 Zarzouna, Bizerte, Tunisia

b Plate-forme Protéomique Toulouse Midi-Pyrénées, IFR40 CNRS, Pôle de Biotechnologie végétale 24 chemin de Borderouge, BP 42617 Auzeville, F-31326 Castanet Tolosan, France

${ }^{\mathrm{c}}$ Surfaces Cellulaires et Signalisation chez les Végétaux, UMR 5546 CNRS-Université Toulouse III, 24 chemin de Borderouge, BP 42617 Auzeville, F-31326 Castanet Tolosan, France

*Corresponding author: Fax: +21672590566

e-mail address: ezzferjani@yahoo.fr (E. El Ferjani) 


\begin{abstract}
Treatment of 14 day-old sunflower seedlings with a toxic amount of copper (50 $\mu \mathrm{M}$ of $\mathrm{CuSO}_{4}$ ) during 5 days caused significant increase in peroxidase activity in roots. Qualitative analysis of soluble proteins using native anionic PAGE followed by detection of peroxidase activity guaïacol as electron donor in the presence of $\mathrm{H}_{2} \mathrm{O}_{2}$ revealed 5 stimulated peroxidases, named A1, A2, A3, A4, and A5. These peroxidases had differential behavior during the period of treatment. A1, A2, A3 and A4 were stimulated in the first period of stress, but rapidly suppressed at $72 \mathrm{~h}$. A5 showed a progressive stimulation which is even increased at $120 \mathrm{~h}$. A1 was partially purified, identified using liquid chromatography coupled to mass spectrometry (LC-MS/MS), and characterized. Effects of $\mathrm{pH}$ and temperature on its activity were determined with guaïacol as electron donor. Optima were obtained at $\mathrm{pH} 8$ and at $40^{\circ} \mathrm{C}$. Analysis of substrate specificity showed that A1 was active on coniferyl alcohol but not on IAA. Enzymatic activity was inhibited by high concentration of $\mathrm{H}_{2} \mathrm{O}_{2}$.
\end{abstract}

Keywords: Copper; Mass spectrometry; Peroxidase; Root; Sunflower 


\section{Introduction}

Peroxidases (EC. 1.11.1.7; donor: hydrogen peroxide oxidoreductase) belong to a large family of heme-containing enzymes which are distributed throughout the plant kingdom. Plant peroxidases can be subdivided into three subgroups (acidic, neutral and cationic) according to their isoelectrophoretic mobilities. These enzymes catalyze the oxidation of a variety of electron donor substrate (e.g. phenols, aromatic amines) by hydrogen peroxide [1]. Based on differences in primary structure, the plant peroxidase superfamily can be divided into three classes: classes I, II and III [2]. Class I peroxidases include intracellular enzymes in plants, bacteria and yeast. Class II peroxidases are extracellular peroxidases of fungi. Class III comprises classical plant secreted peroxidases.

Class III peroxidases have been found in crude plant extracts by staining for activity after separation by gel electrophoresis [3]. These enzymes have approximately 300 amino acids. The majority are $\mathrm{N}$-glycosylated and are predicted to be localized in cell walls or in vacuoles [3]. The amino acid sequences were found to be highly variable inside the plant peroxidase superfamily, with less than $20 \%$ identity in the most divergent cases. The evolution of that multigene family seems to be correlated with the increasing complexity of plant architecture and to the diversification of their biotopes [1]. In some plants like Arabidopsis thaliana, a high duplication rate has led to a large multigene family of 73 members [4].

In plants, peroxidase activity is presumed to be involved in the building and rigidification of cell walls [1], auxin catabolism [5], and senescence [6]. However, their physiological 
functions are not precisely known, as cells contain a large number of peroxidases each having a broad in vitro catalytic specificity [6]. On the other hand, it has been suggested that genetic manipulations using antisense technology or screening of mutants is not a very powerful method for revealing functions of individual peroxidase genes because possible interference from other peroxidase genes may give complex phenotypes [3]. Actually only two A. thaliana peroxidase mutants have yet been described [7]. They are affected in root elongation. On the contrary, plants overexpressing one of these peroxidases have longer roots.

Increase in peroxidase activity was observed in several plants exposed to environmental injury such as biotic and abiotic stresses. It has thus been suggested that these enzymes play key roles in defense mechanisms [8] that are induced in addition to the numerous mechanisms plant possess to reduce damages from exposure to metal ions [9]. In order to understand the role of peroxidases in defense mechanism in response to heavy metals, our laboratory has started the characterization of peroxidases induced by copper in sunflower roots. Actually, copper is known to be an essential micronutrient for higher plants. But, at high levels, it can induce many alterations in plant cells [10]. It can catalyze the formation of some harmful free radicals, which cause an oxidative burst. This toxic effect can be alleviated by several antioxidative systems including peroxidases. In sunflower seedlings treated with $50 \mu \mathrm{M}$ of $\mathrm{CuSO}_{4}, 5$ anionic peroxidases (A1-A5) were induced in a soluble fraction extracted from roots. They had a differential behavior under stress treatment. Here we report the partial purification, the identification and the 
characterization of A1. A1 was identified using liquid chromatography coupled to mass spectrometry (LC-MS/MS).

\section{Results and Discussion}

\subsection{Growth inhibition and copper accumulation in roots under stress conditions}

Forteen day-old sunflower seedlings were cultured on a $50 \mu \mathrm{M} \mathrm{CuSO}_{4}$ for 5 days. This copper excess caused severe symptoms on sunflower roots (Fig. 1A). They became brownish, they showed less branching and reduced growth. Such symptoms were previously described for maize roots treated with nickel [11].

The length of main roots was measured and was found to be significantly shorter in $\mathrm{Cu}$ treated seedlings than in control, with a reduction of about $30 \%$ (Fig. 1B). In the same way, inhibition rate of dry and fresh mass production of $\mathrm{Cu}$-treated roots was estimated at $76 \%$ and $53 \%$ respectively (Fig. 1C and D). All these observations suggest that copper treatment have a strong inhibitory effect on growth. Such effects were also observed on Cannabis sativa roots treated with copper [12]. The high toxicity of copper has been reported for several species including maize [13], tomato [14], bean [15] and cucumber [10]. In some species, high $\mathrm{Cu}$ sensitivity of root growth is related to disturbances of mitosis [16] or to damage of cell membranes [17]. 

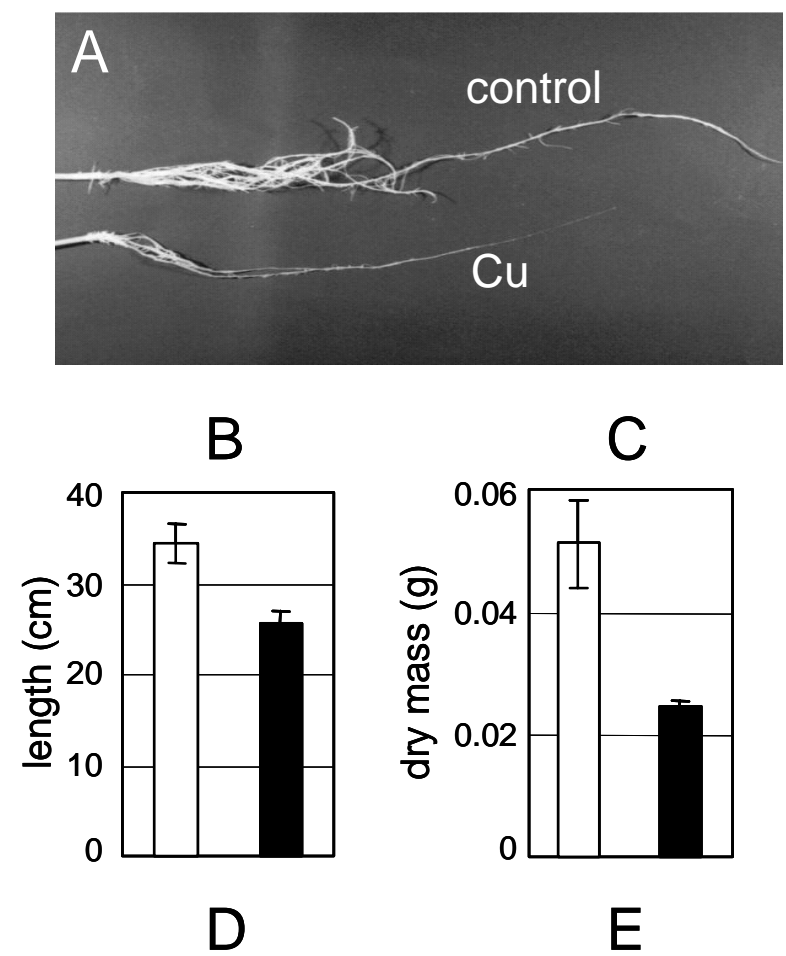

E
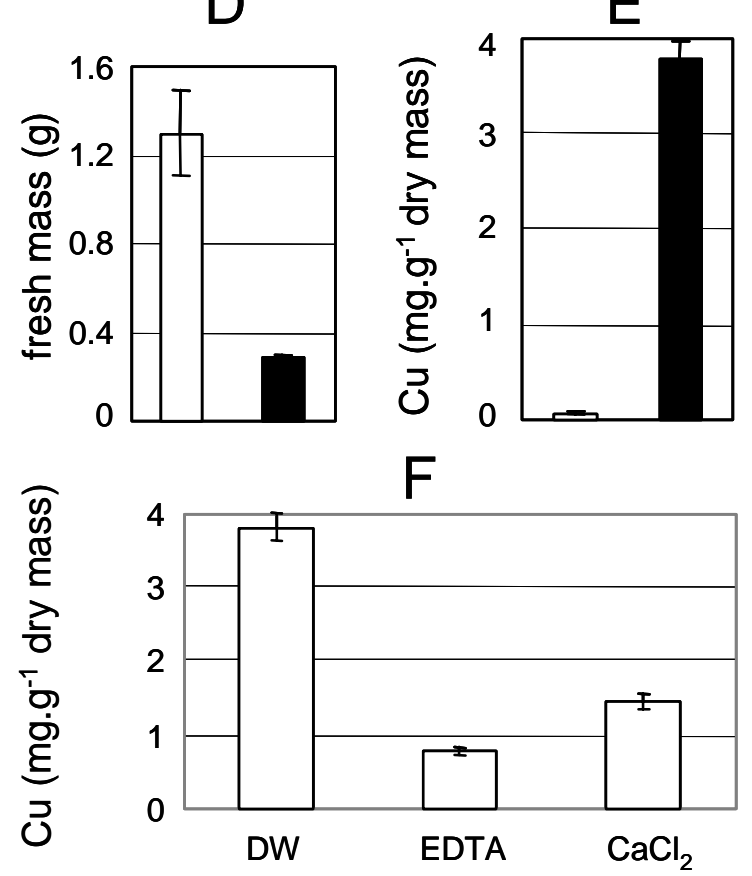

Fig. 1: Effect of cupric stress on root morphology and level of accumulation of

\section{copper in roots}

(A) Morphologic effect of cupric stress on 14 day-old sunflower roots treated with $50 \mu \mathrm{M}$ of $\mathrm{CuSO}_{4}$ during 5 days $(\mathrm{Cu})$ compared to untreated roots (control). (B) Length of main root. (C) Dry mass of roots. (D) Fresh mass of roots. (E) Copper content of 14-day-old sunflower roots grown in control nutrient medium (open bars) or supplemented with $50 \mu \mathrm{M} \mathrm{CuSO}_{4}$ for 5 days (black bars). (F) Estimation of copper content in treated sunflower roots after washing in different solutions: distilled water alone (DW), EDTA (100 mM, $\mathrm{pH}$ 8.0) or $\mathrm{CaCl}_{2}(100 \mathrm{mM})$.

The values are the means of 5 independent experiments. Vertical bars indicate standard errors. 
After copper treatment of seedlings, $\mathrm{Cu}$ content of the roots was measured. It was first estimated at $3.7 \mathrm{mg} \cdot \mathrm{g}^{-1}$ of dry mass (Fig. 1E). However, since copper ions could be adsorbed onto root cell walls and especially on pectins, this value could be overestimated [18]. Thus, in order to eliminate adsorbed ions, roots were washed either with a chelating agent, i.e. EDTA, or with a competitor for adsorption, i.e. a $\mathrm{CaCl}_{2}$ solution. In these experimental conditions, copper content of roots was found to be 0.78 and $1.50 \mathrm{mg}$. $\mathrm{g}^{-1}$ of dry mass respectively (Fig. 1F). Actually, copper accumulation in roots can be considered as a mechanism of defense against metal toxicity by limiting their translocation to the photosynthetic tissues [19].

2.2. Effect of copper excess on total peroxidase activity and PAGE analysis of anionic peroxidases

This important accumulation of $\mathrm{Cu}$ in roots was accompanied by the stimulation of soluble peroxidases. Total peroxidase activity was measured in roots at various times after transfer of seedlings in $50 \mu \mathrm{M}$ of $\mathrm{CuSO}_{4}$, i.e. $0,24,48,72$ and $120 \mathrm{~h}$. Same fractions were submitted to native PAGE (polyacrylamide gel electrophoresis) in order to separate anionic peroxidases. A significant increase in total peroxidase activity was observed $24 \mathrm{~h}$ after the beginning of the $\mathrm{Cu}$ treatment (Fig. 2A). This increase was continued during all the period of treatment. Such an increase in total peroxidase activity in response to copper treatment was already reported in leaves of Commoelina communis [20], in peanut roots [21], in roots of Raphanus sativus [22], and in wheat roots [23]. On the contrary, proteomic analysis of Cannabis sativa roots showed that a peroxidase disappeared in response to an excess of copper [12]. 

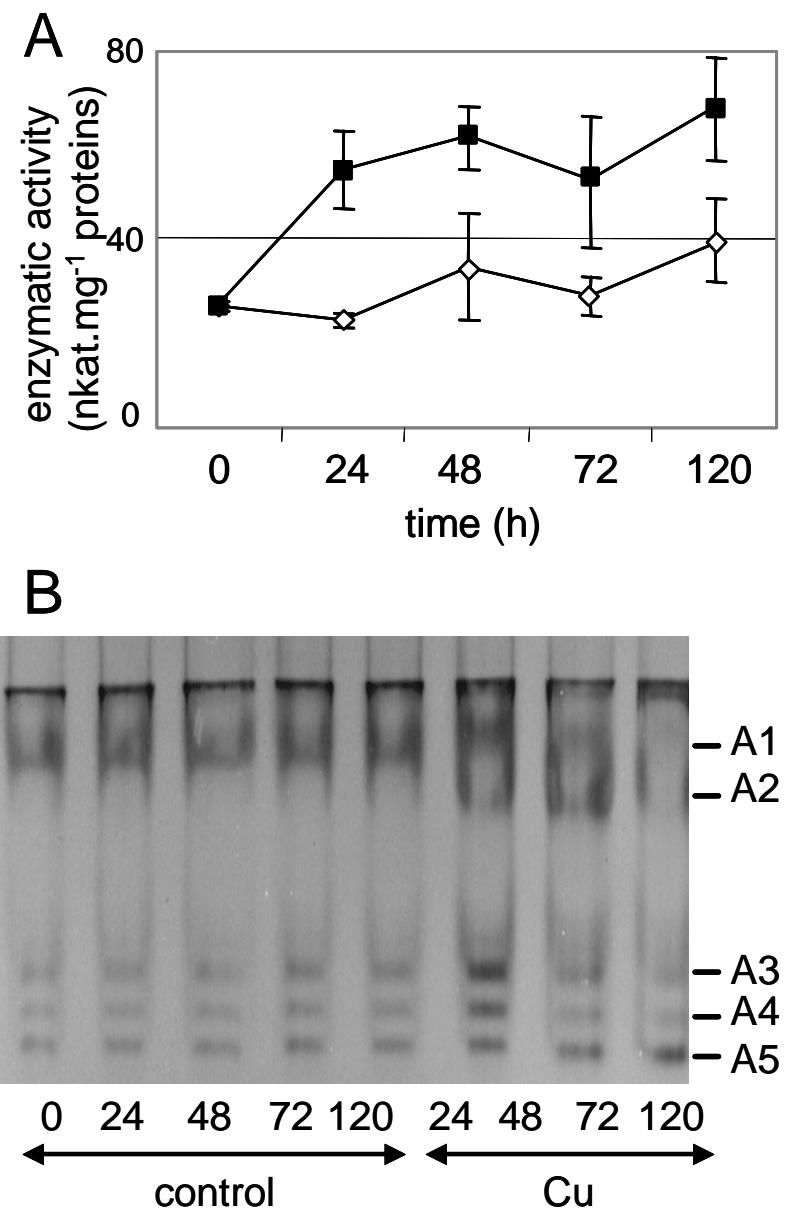

Fig. 2: Peroxidase activity in sunflower roots in response to copper treatment.

(A) Guaïacol peroxidase activity in soluble fraction extracted from control (open diamonds) and $\mathrm{Cu}$-treated (black squares) roots at various times after beginning of $\mathrm{Cu}$ treatment. Values are the means of 5 independent experiments. Vertical bars indicate standard errors. (B) Anionic peroxidase patterns in soluble root extracts of 14 day-old sunflower seedlings grown in control nutrient medium (control) or supplemented with $50 \quad \mathrm{M} \mathrm{CuSO}_{4}$ for $24 \mathrm{~h}$ to $120 \mathrm{~h}(\mathrm{Cu})$. Peroxidases (A1-A5) were separated by anionic PAGE (10\% acrylamide) and their enzymatic activity was revealed with guaïacol as a substrate as described in Material and methods. Fifty $\mu \mathrm{g}$ of proteins were loaded on each lane. 
Qualitative analysis of anionic peroxidases during stress conditions by native PAGE is shown in Fig. 2B. It revealed the presence of 5 peroxidases, named A1 to A5. Copper treatment caused the stimulation of 4 peroxidases (A1, A3, A4 and A5) and the de novo induction of A2. While this stimulation decreased $72 \mathrm{~h}$ after beginning of treatment for A1, A2, A3 and A4, the stimulation of A5 continued. Such variations in the peroxidase pattern of sunflower leaves were described in response to iron deficiency [24]. Several anionic peroxidases associated to cell walls were found to disappear. The fact that several peroxidases exist in sunflower was expected since peroxidases usually belong to large multigene families [4]. Moreover, first data on systematic sequencing of sunflower expressed sequence tags (ESTs) indicate the presence of sequences showing homologies to 25 different peroxidases of $A$. thaliana (http://cgpdb.ucdavis.edu/).

\subsection{Partial purification of A1}

In this paper, we focused our study on A1, since its activity is transiently stimulated in response to copper treatment. In order to avoid difficulties associated with phenolic compounds present in sunflower roots, extracts were prepared after homogenization in phosphate buffer containing $10 \%$ PVP $(\mathrm{w} / \mathrm{w})$. The resulting supernatant had a peroxidase specific activity of 58.45 nkat.mg ${ }^{-1}$ proteins (Table 1). Crude extract was desalted using size-exclusion chromatography on a Sephadex G25 column. Peroxidase activity was recovered in the void volume with a specific activity of 65.13 nkat.mg ${ }^{-1}$ proteins (Table $1)$. 
Table 1. Yield of purification of A1 from sunflower roots at the three steps of the procedure. Enzymatic activity was assayed with guaïacol as a substrate.

\begin{tabular}{lllll}
\hline Step of purification & $\begin{array}{l}\text { Volume } \\
(\mathrm{mL})\end{array}$ & $\begin{array}{l}\text { Protein } \\
\text { content } \\
(\mathrm{mg})\end{array}$ & $\begin{array}{l}\text { Specific } \\
\text { activity } \\
\text { (nkat.mg }\end{array}$ & $\begin{array}{l}\text { Purification } \\
\text { rate }\end{array}$ \\
\hline Crude extract & 25 & 3.7 & 58.45 & 1.0 \\
\hline G25 & 26 & 3.6 & 65.13 & 1.1 \\
\hline $\begin{array}{l}\text { Fast Flow Q Sepharose } \\
\text { (peak 1) }\end{array}$ & 1.2 & 0.016 & 2196.05 & 38.0 \\
\hline
\end{tabular}

Next step of the purification consisted in anionic exchange chromatography on a Fast Flow Q Sepharose column. The column was equilibrated with $100 \mathrm{mM}$ Tris-HCl buffer ( $\mathrm{pH} 7.5)$. A linear gradient of $\mathrm{NaCl}(0-0.4 \mathrm{M})$ was applied. Two peaks of peroxidase activity were obtained: peak 1 at $0.04 \mathrm{M} \mathrm{NaCl}$, peak 2 at $0.16 \mathrm{M} \mathrm{NaCl}$ (Fig. 3A). Specific activity in peak 1 was 2196.05 nkat.mg ${ }^{-1}$ proteins, corresponding to a purification factor of 38 (Table 1). Analysis by native PAGE showed that fractions corresponding to peak 1 contained A1, whereas fractions corresponding to peak 2 contained A4 and A5 (Fig. 3B). The fraction containing A1 was further analysed by SDS-PAGE followed by silver staining (Fig. 3C). Only a few bands were visible, showing the efficiency of this purification step. 

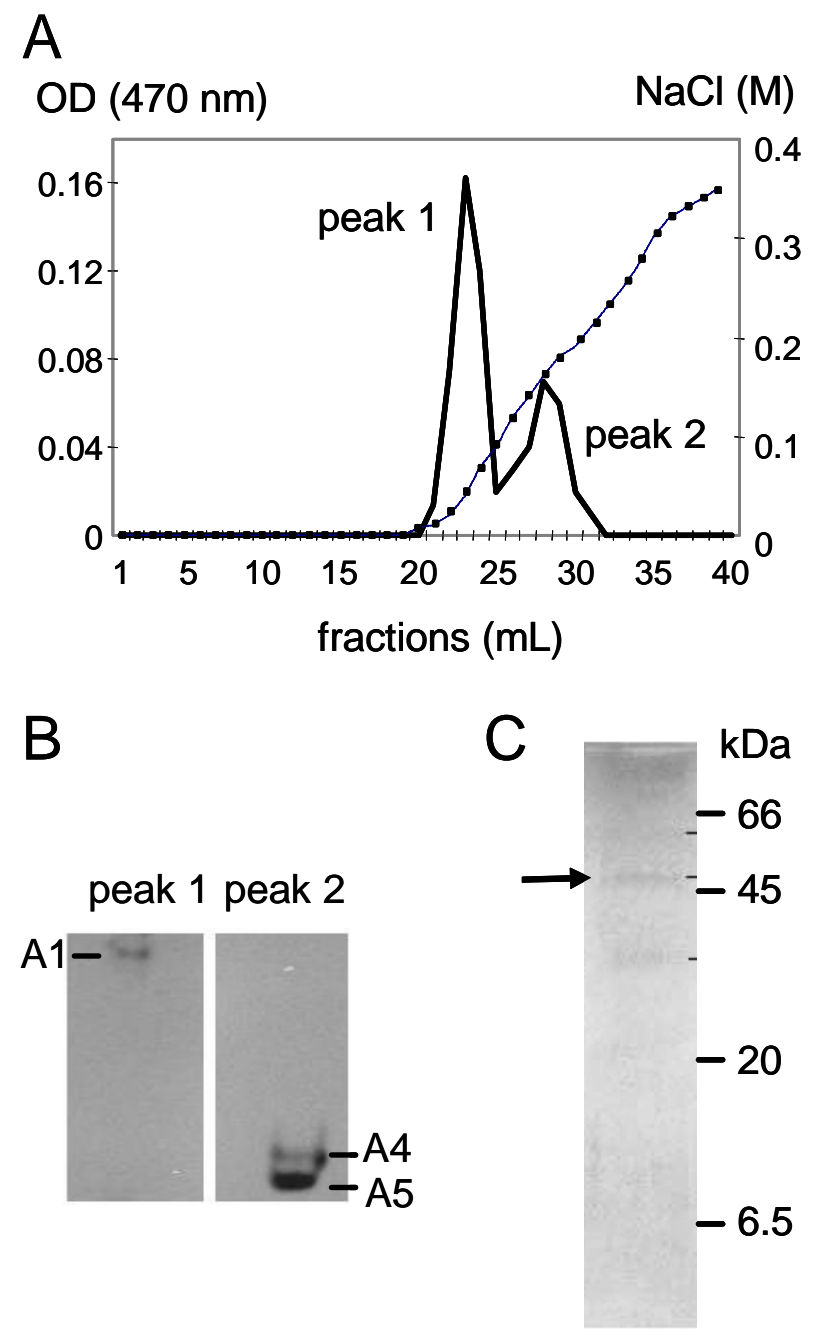

Fig. 3: Partial purification of the A1 peroxidase. (A) Anionic exchange chromatography on Fast Flow Q-Sepharose.

Elution of proteins was carried out with a linear gradient of $\mathrm{NaCl}(0-0.4 \mathrm{M})$ indicated by a dotted line. Enzymatic activity was detected using guaïacol as a substrate (black continuous line). (B) Detection of peroxidases in peaks 1 and 2 after anionic PAGE (10\% acrylamide) using guaïacol as a substrate. (C) Analysis of peak 1 by SDS-PAGE and staining with silver nitrate. The band of $47 \mathrm{kDa}$ which was further analyzed by LC-MS/MS is indicated with an arrow. 


\subsection{Identification of A1 by LC-MS/MS}

Considering the average molecular mass of $35-40 \mathrm{kDa}$ of peroxidases, the band of apparent molecular mass of $47 \mathrm{kDa}$ was the best candidate to contain a sunflower peroxidase responsible for the enzymatic activity measured in peak 1 . It was further analyzed by LC-MS/MS.

Peptides coming from trypsin digestion of the $47 \mathrm{kDa}$ polypeptide were analysed by LCMS/MS. The sequences of 3 peptides showing homology to peroxidases could be obtained with a high level of confidence (Table 2, Table 1 supplementary data). Several ESTs covering the N-terminus region of Helianthus peroxidases and containing 2 peptides (AQAFVIIENLR and YYVDLMNR) could be found among which: $H$. paradoxus $\underline{\mathbf{C F 0 8 3 9 2 1}}, H$. annuus $\underline{\mathbf{D Y 9 2 6 1 9 1}}$ and $H$. annuus $\underline{\mathbf{D H 9 1 8 0 4 1}}$. One EST covering the C-terminus of a $H$. argophyllus peroxidase ( $\underline{\mathbf{C F 0 9 6 5 3 5}}$ ) and containing 2 peptides (YYVDLMNR and MGQLSVLTGTQGEIR) allowed getting a complete sequence. These sequences were used to find homologous plant sequences with the BLAST software. Best hits were the A. thaliana AtPrx12 (At1g71695) and the Nicotiana tabacum NtPER9_6 peroxidases (Fig. 4). Search for functional domains using InterProScan indicated that such protein are bona fide peroxidases containing functional domains PF00141 (peroxidase), PS50873 (Plant heme peroxidase family profile), PS00435 (Peroxidases proximal heme-ligand signature) and PS00436 (Peroxidases active site signature). Amino acids important for protein structure such as Cys, or for active site such as Arg, Asn, Pro, His, and Asp are well-conserved (Fig. 4). All these proteins have a C-terminal extension that is assumed to be cleaved to get full activity [4]. 
Table 2. Sequences of the 3 peptides obtained through LC-MS/MS and showing identity to amino acid sequences of Helianthus peroxidases.

Sequences are written using the one-letter code. Database searching was performed using the Mascot software and a Helianthus EST database as described in Material and methods. In those conditions, individual ion scores are significant when higher than 48. Mascot search results are given in Table 1 (supplementary data).

\begin{tabular}{|c|c|c|}
\hline Sequences of peptides & $\begin{array}{l}\text { MASCOT } \\
\text { score }\end{array}$ & $\begin{array}{l}\text { Accession numbers } \\
\text { of the corresponding Helianthus EST }\end{array}$ \\
\hline \multirow[t]{3}{*}{ AQAFVIIENLR } & 51 & H. paradoxus $\underline{\text { CF083921 }}$ \\
\hline & & H. annuus $\underline{\mathbf{D Y 9 2 6 1 9 1}}$ \\
\hline & & H. annuus $\underline{\mathbf{D H} 918041}$ \\
\hline \multirow[t]{4}{*}{ YYVDLMNR } & 34 & H. paradoxus $\underline{\text { CF083921 }}$ \\
\hline & & H. annuus $\underline{\mathbf{D Y 9 2 6 1 9 1}}$ \\
\hline & & H. annuus DH918041 \\
\hline & & H. argophyllus $\underline{\text { CF096535 }}$ \\
\hline MGQLSVLTGTQGEIR & 60 & H. argophyllus CF096535 \\
\hline
\end{tabular}

When Mascot search was performed against the Viridiplantae database, it should be mentioned that an additional peptide was found in the $47 \mathrm{kDa}$ band (NLVTLLNK) (Table 2 supplementary data). This peptide had a significant Mascot score of 45 (score higher than 43 was required in these conditions). Such a sequence is found in a $H$. annuus protein $(\underline{\mathbf{A A L 7 7 1 0 3}})$ that is predicted to be secreted by both PSORT and TargetP. This protein contains two functional domains: FAD-binding domain (PF01565) and Berberine and berberine-like domain (PF08031). It is a good candidate to be a protein homologous to berberine-brige oxido-reductases that were described in many cell wall proteomes [25]. The precise roles of such proteins in plant cell walls are not known.

This analysis allowed the identification of two proteins, among which a peroxidase probably contributing to the reaction of sunflower roots to cupric stress. This peroxidase 
is predicted to be secreted. It is the first time that a sunflower peroxidase can be precisely identified using LC-MS/MS. It will allow further characterization of the protein as well as study of the fine regulation of gene expression in response to cupric stress.

\subsection{Characterization of the enzymatic activity of A1}

To further characterize the enzymatic activity of A1, it was tested in different experimental conditions of $\mathrm{pH}$, temperature and $\mathrm{H}_{2} \mathrm{O}_{2}$ concentration (data not shown). At $25^{\circ} \mathrm{C}$, A1 showed an optimum of activity at $\mathrm{pH} 8$. In the same way, it has been reported that African oil palm tree anionic peroxidases showed a optimum of activity at alkali $\mathrm{pH}$ as well as a high stability [26]. At $\mathrm{pH} 6.5, \mathrm{~A} 1$ had the highest enzymatic activity at $40^{\circ} \mathrm{C}$. Also, it has been demonstrated that corn root peroxidases presented a high activity at high temperature, that is around $50{ }^{\circ} \mathrm{C}$ [27]. Concerning the substrate specificity (Table 3 ), A1 had an affinity 10 times higher for coniferyl alcohol than for guaïacol. No reaction was observed using indole acetic acid (IAA). Coniferyl alcohol is one of the first precursors for lignin biosynthesis in plants [28]. Thus the possible involvement of A1 in lignification

process could be suggested. However, this assumption should be checked in vivo. Finally, A1 activity was decreased by $30 \%$ already at $20 \mathrm{mM} \mathrm{H}_{2} \mathrm{O}_{2}$ in the incubation medium as compared to standard conditions $\left(10 \mathrm{mM} \mathrm{H}_{2} \mathrm{O}_{2}\right)$. Increasing $\mathrm{H}_{2} \mathrm{O}_{2}$ concentration up to 50 $\mathrm{mM}$ resulted in a further decrease of $30 \%$ of activity. This was observed in previous works showing the inactivation of peroxidases by hydrogen peroxide [26]. 


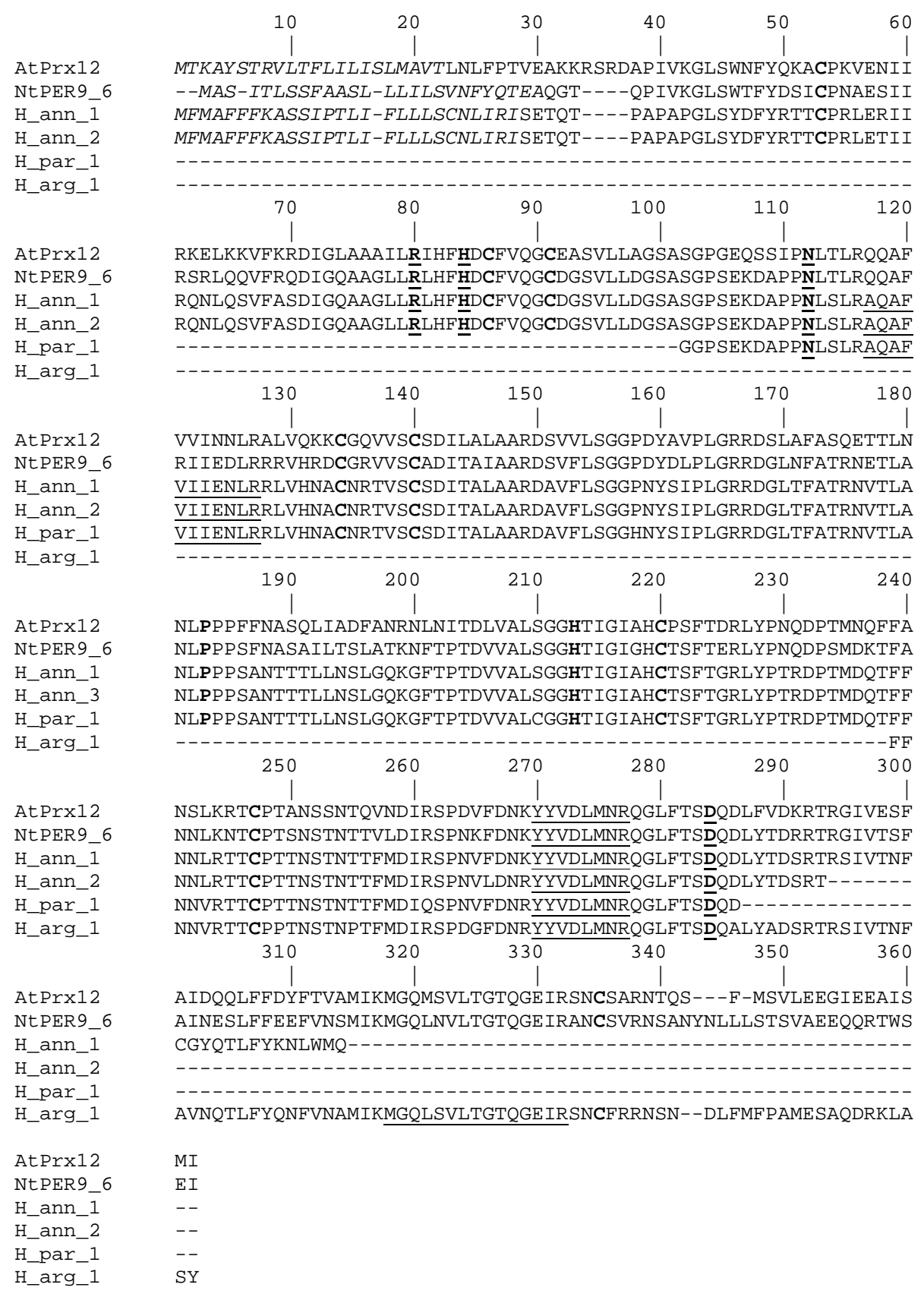

Fig. 4: Amino acid sequences of fragments of Helianthus peroxidases comprising peptides identified by LC-MS/MS.

H_ann_1 and H_ann_1 derive from H. annuus ESTs DY926191 and DH918041 respectively. H_par_1

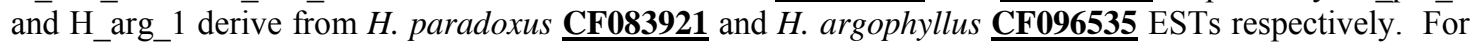
comparison, two closely related sequences from A. thaliana (Atlg71695, AtPrx12, NP 177313) and $N$. tabacum (Nt PER9_6, $\underline{\text { AAK52084) }}$ ) are indicated. Peptides identified by LC-MS/MS are underlined. Note that closely related peptides are present in the A. thaliana and $N$. tabacum peroxidase sequences. Predicted signal peptides are in italics. Conserved Cys residues forming disulfide bridges are in bold. Active site residues are in bold underlined. 
These modulations of peroxidase activities in response to variations in temperature, $\mathrm{pH}$, or $\mathrm{H}_{2} \mathrm{O}_{2}$ concentration could be considered as regulatory processes acting under physiological modifications to favour some biochemical processes. It has been suggested that small variations in $\mathrm{pH}$ values could represent efficient in vivo regulatory ways to shift optimal conditions from one peroxidase to another and thereby favor one of the different processes connected to cell wall metabolism and preferentially catalyzed by specialized peroxidases [29]. Thus, peroxidase activities could be regulated during development or in response to stress factors [30].

\section{Conclusion}

We showed that cupric stress caused the stimulation of total peroxidase activity in 14 day-old sunflower roots. Several anionic peroxidases seemed to contribute to this increase of peroxidase activity. The A1 peroxidase was identified through de novo sequencing of 3 peptides thanks to mass spectrometry analysis. It showed high level of identity to the AtPrx12 A. thaliana and the NtPER9_6 N. tabacum peroxidases. In order to fully understand the role of peroxidases in defense mechanisms against cupric stress, our work is now in progress to purify and characterize the other peroxidases (A2-A5).

\section{Materials and methods}

\subsection{Plant material}

Sunflower (Helianthus annuus L. var. Dorra RM) seedlings were grown for 14 days in nutrient solution. $\mathrm{Cu}$ treatment was performed as previously described [14]. Roots were collected from 19 day-old plants with and without treatments with $50 \mu \mathrm{M}$ of $\mathrm{CuSO}_{4}$. 


\subsection{Metal analysis}

For copper analysis, roots were subdivided in 3 samples which were washed for $10 \mathrm{~min}$ with either distilled water, EDTA $(100 \mathrm{mM}, \mathrm{pH} 8.0)$ or $\mathrm{CaCl}_{2}(100 \mathrm{mM})$. Roots were dried and subsequently digested in $65 \%$ nitric acid $(1 \mathrm{~mL} / 0.1 \mathrm{~g}$ of dry matter). The digested material was resuspended in distilled water. $\mathrm{Cu}$ content was determined using an atomic absorption spectrophotometer (Perkin Elmer 2380 Atomic Spectrometer, Waltham, MA, USA).

\subsection{Peroxidase extraction and partial purification}

Sunflower roots $(20 \mathrm{~g})$ were homogenized in a mortar at $0^{\circ} \mathrm{C}$ with $50 \mathrm{mM}$ phosphate buffer $\left(\mathrm{KH}_{2} \mathrm{PO}_{4} / \mathrm{K}_{2} \mathrm{HPO}_{4}\right)$, pH 7.0 containing $0.2 \mathrm{mM}$ EDTA and $10 \%(\mathrm{w} / \mathrm{w}) \mathrm{PVP}$. Homogenates were centrifuged at $10000 \mathrm{~g}$ for $15 \mathrm{~min}$. Supernatant was used as crude extract for further purification and measurement of total peroxidase activity. Peroxidase activity was determined spectrophotometrically in the presence of $\mathrm{H}_{2} \mathrm{O}_{2}$ using guaïacol as an electron donor [31].

Crude extract was desalted through size-exclusion chromatography (G25 Sephadex, GE Healthcare Life Sciences, Saclay, France) using the phosphate buffer described above. Resulting fractions were loaded on a $1 \mathrm{~mL}$ Fast Flow Q-Sepharose (HiTrap Q FF, GE Healthcare Life Sciences, Saclay, France) equilibrated with $100 \mathrm{mM}$ Tris-HCl, pH 7.5. Anionic peroxidases were eluted with a linear gradient of $\mathrm{NaCl}(0-0.4 \mathrm{M})$ at a flow rate of $0.5 \mathrm{~mL} / \mathrm{min}$. Protein quantification was performed using the method of Bradford [32] using bovine serum albumine (BSA) as a standard. Peroxidase activity was detected in 
eluted fractions using guaïacol as a substrate. To be monitored on a native PAGE, fractions were dialyzed against $50 \mathrm{mM}$ Tris- $\mathrm{HCl}(\mathrm{pH} 7.5)$ buffer. Aliquots were also monitored by SDS-PAGE.

\subsection{In vitro tests of A1 activity}

The enzymatic activity was measured in a total volume of $2 \mathrm{~mL}$. The effect of temperature on A1 was studied after heating of buffer solution $(50 \mathrm{mM}$ phosphate buffer, $\mathrm{pH} 6.5 ; 10 \mathrm{mM} \mathrm{H}_{2} \mathrm{O}_{2}$,

$9 \mathrm{mM}$ guaiacol) at desired temperature for $15 \mathrm{~min}$. Twenty $\mu \mathrm{L}$ (16 $\mu \mathrm{g}$ proteins) of peak 1 fractions (see Fig. 3) were added and the oxidation of guiacol was monitored by the increase of absorbance at $470 \mathrm{~nm}$.

$\mathrm{pH}$ effect on A1 was studied in the same buffer at different $\mathrm{pH}$ from 3 to 9 . A1 was incubated at $25{ }^{\circ} \mathrm{C}$, then $20 \mu \mathrm{L}(16 \mu \mathrm{g}$ proteins) of peak 1 fractions (see Fig. 3$)$ were added to each sample and their activity were measured as described previously.

Assays towards coniferyl alcohol and IAA were performed according to [28] and [33]. Twenty $\mu \mathrm{L}$ (16 $\mu \mathrm{g}$ proteins) of peak 1 fractions (see Fig. 3) were used for each test.

\subsection{Identification of the A1 peroxidase by mass spectrometry}

After SDS-PAGE, the silver-stained band of $47 \mathrm{kDa}$ was cut into 3 pieces of $1 \mathrm{x} 1 \mathrm{~mm}$. Gel pieces were washed in $25 \mathrm{mM}$ ammonium bicarbonate, acetonitrile (ACN) $50 \%$. After ACN removal, gel pieces were dried at room temperature, covered with a trypsin (PROMEGA, Charbonnières, France) solution at $10 \mathrm{ng} / \mu \mathrm{L}$ in $25 \mathrm{mM} \mathrm{NH}_{4} \mathrm{HCO}_{3}$, and incubated overnight at $38^{\circ} \mathrm{C}$. The supernatant was collected. An $\mathrm{H}_{2} \mathrm{O} / \mathrm{ACN} / \mathrm{HCOOH}$ 
(59:40:1) solution was added onto gel slices. Extraction of peptides was performed under rotary shaking for $15 \mathrm{~min}$ at room temperature. Extraction step was repeated with the $\mathrm{H}_{2} \mathrm{O} / \mathrm{ACN} / \mathrm{HCOOH}(74: 25: 1)$ solution. Supernatants were pooled and concentrated in a vacuum centrifuge to a final volume of $5 \mu \mathrm{L}$. Twenty $\mu \mathrm{L}$ of an $\mathrm{H}_{2} \mathrm{O} / \mathrm{ACN} / \mathrm{HCOOH}$ (98:2:0.1) solution was added before LC-MS/MS analysis.

Peptide mixture was analyzed by on-line nano-HPLC (LC Packings, Amsterdam, The Netherlands) coupled to a nanospray Q-TRAP mass spectrometer (Applied Biosystems/MDS Sciex, Foster City, CA, USA) as described previously [34].

Data were searched by Mascot through Analyst 1.4 interface (Applied Biosystems/MDS Sciex, Foster City, Ca, USA) against the subset Viridiplantae of NCBI nr database and against an Expressed Sequence Tag (EST) library of the Helianthus genus downloaded on 1/07/2007 (http://www.ncbi.nlm.nih.gov/). The search parameters were as follows. Mass accuracy of the mono-isotopic peptide precursor and peptide fragments was set to $0.5 \mathrm{Da}$ and $0.4 \mathrm{Da}$ respectively. Oxidation of Met $(+16)$ and deamidation $(+1)$ of Asp or Gln were considered as differential modifications. Two missed trypsin cleavages were allowed. Only peptides with an identification confidence higher than $95 \%$ were considered. All MS/MS spectra corresponding to these peptides were manually checked.

\subsection{Bioinformatic analysis of nucleic acid and protein sequences}

The presence of signal peptides was predicted using PSORT (http://psort.ims.utokyo.ac.jp/form.html), and TargetP (http://www.cbs.dtu.dk/services/TargetP/). Functional annotation was done using InterProScan (http://www.ebi.ac.uk/InterProScan/). 
Search for protein sequences homologous to Helianthus peroxidases was performed using BLAST (http://www.ncbi.nlm.nih.gov/BLAST/).

\section{Acknowledgements}

The authors thank the Ministry of Higher Education and Scientific Research, Tunisia, Université Paul Sabatier-Toulouse III, and CNRS, France, for supporting this project. LC-MS/MS analyses were performed on Plate-forme de Protéomique de la Génopole Toulouse Midi-Pyrénées. The authors wish to thank Prof. Philippe Behra (ENSIACETINP Toulouse, France) for stimulating discussions. They are grateful to Mr Bechir Azib for skilful technical assistance. 


\section{References}

[1] Passardi F., Penel C., Dunand C., Performing the paradoxical: how plant peroxidases modify the cell wall, Trends Plant Sci. 9 (2004) 534-540.

[2] Welinder K.G., The plant peroxidase superfamily, in: Labarzewski J., Greppin H., Penel C., Gaspar Th. (Eds.), Biochemical, Molecular and Physiological Aspects of Plant Peroxidases, University of Geneva, Switzerland, 1991, pp. 3-13.

[3] Hiraga S., Sazaki K., Ito H., Ohashi Y., Matsui H., A large Family of class III Plant Peroxidases. Plant Cell Physiol. 42 (2001) 462-468.

[4] Welinder K.G., Justesen A.F., Kjærsgård I.V.H., Jensen R.B., Rasmussen S.K., Jespersen H.M., Duroux L., Structural diversity and transcription of class III peroxidases from Arabidopsis thaliana, Eur. J. Biochem. 269 (2002) 6063-6081.

[5] Delannoy E., Marmey P., Penel C., Nicole M., Les peroxydases végétales de la classe III, Acta Bot. Gallica 151 (2004) 353-380.

[6] Faivre-Rampant O., Kevers C., Bellini C., Gaspar T., Peroxidase activity, ethylene production, lignification and growth limitation in shoots of a non rooting mutant of tobacco, Plant Physiol. 36 (1998) 837-877.

[7] Passardi F., Tognolli M., De Meyer M., Penel C., Dunand C., Two cell wall associated peroxidases of Arabidopsis influence root elongation, Planta 223 (2006) 965974.

[8] Passardi F., Cosio C., Penel C., Dunand C., Peroxidases have more functions than a Swiss army knife, Plant Cell Report 24 (2005) 255-265. 
[9] Clemens S., Molecular mechanisms of plant metal tolerance and homeostasis, Planta 212 (2001) 475-486.

[10] Vinit-Dunand F., Epron D., Alaoui-Sossé B., Badot P.M., Effects of copper on growth and on photosynthesis of mature and expanding leaves in cucumber plants, Plant Sci. 163 (2002) 53-58

[11] Baccouche S., Chaoui A., El Ferjani E., Nickel induced oxidative damage and antioxidant responses in Zea mays shoots, Plant Physiol. Biochem. 36 (1998) 689-694.

[12] Bona E., Marsano F., Cavaletto M., Berta G., Proteomic characterization of copper stress response in Cannabis sativa roots, Proteomics 7 (2007) 1121-1130.

[13] Mocquot B., Vangronsveld J., Clijsters H., Mench M., Copper toxicity in young maize (Zea mays L.) plants: Effects on growth, mineral and chlorophyll contents, and enzyme activities, Plant Soil 182 (1996) 287-300.

[14] Mazhoudi S., Chaoui A., Ghorbal M.H., El Ferjani E., Response of antioxidant enzymes to excess copper in tomato (Lycopersicon esculentum, Mill.), Plant Sci. 127 (1997)182-186.

[15] Gupta M., Cuypers A., Vangronsveld J., Clijsters H., Copper affects the enzymes of the ascorbate-glutathione cycle and its related metabolites in roots of Phaseolus vulgaris, Physiol. Plant. 106 (1999) 262-267.

[16] Eleftheriou E.P., Karataglis S., Ultrastructural and morphological characteristics of cultivated wheat growing on copper-polluted fields, Bot. Acta 102 (1989) 134-140.

[17] De Vos C.H.R., Ten Bookum W.M., Vooijs R., Shat H., De Kok L.J., Effect of copper on fatty acid composition and peroxidation of lipids on roots of tolerant and sensitive Silene cucubalus. Plant. Physiol. Biochem. 31 (1993) 151-158. 
[18] Kartel M.T., Kupchik LA, Veisov B.K., Evaluation of pectin binding of heavy metal ions in aqueous solutions, Chemosphere 38 (1999) 2591-2596.

[19] Zhang Z.Q., Wong M.H., Nie X.P., Lan C.Y., Effects of zinc (zinc sulfate) on rhizobia-earleaf acacia (Acacia auriculaeformis) symbiotic association. Bioresource Technol. 64 (1998) 97-104

[20] Wang H., Shan X-q, Wen B. Zhang S., Wang Z-j., Responses of antioxidative enzymes to accumulation of copper in a copper hyperaccumulator of Commoelina communis, Arch. Environ. Contam. Toxicol. 47 (2004) 185-192.

[21] Li T.C., Feng T.Y., Chen W.S., Liu Z.H., The acute effect of copper on the levels of indole-3-acetic acid and lignin in peanut roots, Aust. J. Plant Physiol. 28 (2001) 1-6.

[22] Chen E.L., Chen Y.A., Chen L.M., Liu Z.H., Effect of copper on peroxidase activity and lignin content in Raphanus sativus, Plant Physiol. Biochem. 40 (2002) 439444.

[23] Sgherri C., Teresa M., Milone A., Clijsters H., Navarri-Izzo F., Antioxidative enzymes in two wheat cultivars, differently sensitive to drought and subjected to subsymptomatic copper doses, J. Plant Physiol. 158 (2001) 1439-1447.

[24] Ranieri A., Castagna A., Baldan B., Soldatini G.F., Iron deficiency differently affects peroxidase isoforms in sunflower, J. Exp. Bot. 52 (2001) 25-35.

[25] Jamet E., Canut H., Boudart G., Pont-Lezica R., Cell wall proteins: a new insight through proteomics, Trends Plant Sci. 11 (2006) 33-39.

[26] Sakharov I.Y., Sakharova I.V., Extremely high stability of African oil palm tree peroxidases, Biochim. Biophys. Acta 1598 (2002) 108-114. 
[27] Mika A, Lüthge S., Properties of guaïacol peroxidase activities isolated from corn root plasma membranes, Plant Physiol. 132 (2003) 1489-1498.

[28] Sato Y., Sugiyama M., Komamine A., Fukuda H., Separation and characterization of the isoenzymes of wall-bound peroxidase from cultured Zinnia cells during tracheary element differentiation, Planta 196 (1995) 141-147.

[29] de Marco A., Guzzardi P., Jamet E., Isolation of tobacco isoperoxidases accumulated in cell-suspension culture medium and characterization of activities related to cell wall metabolism, Plant Physiol. 120 (1999) 371-382.

[30]Mohan R., Vijayan P., Kolattukudy P.E., Developmental and tissue-specific expression of a tomato anionic peroxidase (tap1) gene by a minimal promoter, with wound and pathogen induction by an additional 5'-flanking region. Plant Mol. Biol. 22 (1993) 475-490.

[31] Fielding J.L., Hall J.L., A biochemical and cytochemical study of peroxidase activity in roots of Pisum sativum, J. Exp. Bot. 29 (1978) 969-981.

[32] Bradford M., A rapid and sensitive method for the quantification of mg quantities of protein, Anal. Chem. 72 (1976) 248-254.

[33] de Forchetti S.M., Tigier H.A., Effect of dicarboxylic acids on the peroxidaseIAA oxidase isozymes of soybean callus, J. Plant Physiol. 59 (1983) 355-358.

[34] Boudart G., Jamet E., Rossignol M., Lafitte C., Borderies G., Jauneau A., Esquerré-Tugayé M.-T., Pont-Lezica R., Cell wall proteins in apoplastic fluids of Arabidopsis thaliana rosettes: identification by mass spectrometry and bioinformatics, Proteomics 5 (2005) 212-221. 